\title{
A Review of Conventional and Contemporary Luting Agents Used in Dentistry
}

\author{
Sita Ramaraju DV ${ }^{1}$, Rama Krishna Alla ${ }^{2, *}$, Venkata Ramaraju Alluri ${ }^{3}$, Raju MAKV ${ }^{4}$ \\ ${ }^{1}$ Department of Conservative Dentistry \& Endodontics, Vishnu Dental College, Bhimavaram, West Godavari, Andhra Pradesh, India \\ ${ }^{2}$ Department of Dental Materials, Vishnu Dental College, Bhimavaram, West Godavari, Andhra Pradesh, India \\ ${ }^{3}$ Department of Prosthodontics, Vishnu Dental College, Bhimavaram, West Godavari, Andhra Pradesh, India \\ ${ }^{4}$ Department of Orthodontics, Vishnu Dental College, Bhimavaram, West Godavari, Andhra Pradesh, India \\ *Corresponding author: ramakrishna.a@vdc.edu.in
}

Received August 01, 2014; Revised August 12, 2014; Accepted August 15, 2014

\begin{abstract}
The selection of an appropriate luting agent influences the long-term clinical success of fixed prosthodontic restorations. There are varieties of luting agents available from conventional water-based to contemporary adhesive resin cements. However, no single luting agent is capable of meeting all the stringent requirements. Introduction of adhesive resin systems has completely changed the face of fixed prosthodontic practice leading to an increased use of bonded all-ceramic crowns and resin-retained fixed partial dentures. This review aims at presenting an overview of current cements and discusses physical properties, biocompatibility and other properties that make particular cement the preferred choice depending on the clinical indication.
\end{abstract}

Keywords: dental luting agents, cements, biocompatibility, film thickness, adhesion

Cite This Article: Sita Ramaraju DV, Rama Krishna Alla, Venkata Ramaraju Alluri, and Raju MAKV, “A Review of Conventional and Contemporary Luting Agents Used in Dentistry." American Journal of Materials Science and Engineering, vol. 2, no. 3 (2014): 28-35. doi: 10.12691/ajmse-2-3-1.

\section{Introduction}

Dental cements are used as luting agents and restorative materials in the oral cavity. The most obvious use of dental cements is for permanently retaining metallic and non-metallic inlays, crowns, and bridges to tooth structure. Cements used in this manner are called Luting agents because they lute, or adhere, one surface to another. Other uses of dental cements include bonding of orthodontic appliances to the teeth and cementing pins and posts to retain restorations. The Use of restorative cements have restricted only to low stress bearing areas since they have low strength compared to resin-based composites and amalgam. Dental cements can also be used as protecting materials after the cavity preparation to protect the pulp against further trauma, like thermal and chemicalinsulating bases under metallic restorations and others like composites restorations and pulp-capping agent and cavity liners. Some fluoride-containing cements can be used as fissure sealants, root canal sealants, and core build-up for restoration of broken-down teeth [1-9]. This article reviews numerous luting cements, their composition, chemistry, properties with their advantages and disadvantages from the literature available in PUBMED and other sources from the past 40 years.

\section{Development of Dental Cements}

Zinc phosphate cement is considered as the oldest luting agent, which was invented by Peirce in 1878 and it has the longest track record as a luting agent to secure cast restoration for more than 130 years. It serves as a standard by which newer systems can be compared [1,2].

In the beginning of the $20^{\text {th }}$ century (1903) Silicate cements were developed. These were the earliest of the direct tooth colored filling materials. The silicate cements may be considered as precursors of more modern products such as composite resin and glass Ionomer cements. The durability of a silicate restoration depends critically on the care taken in handling the material and on the oral hygiene of the patient [2].

In 1968, however, a new kind of cement was produced by D.C. Smith using zinc oxide as powder and polycarboxylic acid as liquid component. The result is the so- called polyacrylate cement. It was the first cement system developed with a potential for adhesion to tooth structure. It is primarily used for cementation of indirect restorations and thermal insulating base [2,10].

Wilson and Kent developed Glass Ionomer Cements in 1969. Glass ionomer cements were developed in an attempt to capitalize on the favourable properties of both silicate and polycarboxylate cements. So, glass ionomer is the generic name of a group of materials that use silicate glass powder and an aqueous solution of polyacrylic acid. This material acquires its name from its formulation of glass powder and an ionomeric acid that contains carboxylic (COOH) groups which help in chemical bonding with the natural tooth and to certain alloys as well. Glass ionomer cements are also referred to as 
polyalkanoate cements or ASPA (Aluminosilicate polyacrylic acid) cement [1,2,3,11]. In 1986, resin modified glass ionomer cements were developed [2].

A variety of resin-based cements have now become available because of the development of the direct filling resins with improved properties, such as the acid-etch technique for attaching resins to enamel and molecules with a potential bond to conditioned dentin with organic or inorganic acid. Some are designed for general use and others for specific uses such as attachment of orthodontic brackets or resin-bonded bridges [2].

\section{Luting Cements}

Luting agents are used like glue to retain the metallic, ceramic and composite crowns, bridges inlays and onlays permanently. In dentistry, use of dental cements as a luting agent is employed for two major purposes such as to secure cast restoration in fixed prosthodontics and to retain orthodontic bands and appliances in position, and to serve as a restorative material either alone or with other materials [2].

Uses of luting cements for fixed prosthodontic purposes, require preparation of the tooth surface (i.e. 1.5 to $2 \mathrm{~mm}$ of enamel and dentin must be removed to create space in which the cement is placed). So the most important aims of the luting cements in fixed prosthodontics are to prevent the bacteria and oral fluids from penetration into the prepared surface and insulate the thermal conduction as well as retention of the restoration by filling the gap between the tooth surface and the restoration [12]. While in orthodontics, the preparation of tooth surface is eliminated (no need to remove any enamel or dentin) where the cements are placed directly on the teeth. However the most important aim of luting cements is to retain the bands in position without detachment.

Various luting cements used for luting of fixed restorations and orthodontic appliances as well are zinc phosphate cements, zinc polycarboxylate cements, glass ionomer cements, hybrid ionomer cements, resin modified glass ionomer cements, polyacid modified resin cements, and resin cement $[1,2,3,4,13,14,15]$.

Table 1. Ideal requirements of dental luting agents

\begin{tabular}{|c|c|}
\hline Properties & Ideal Requirements \\
\hline Biological & $\begin{array}{l}\text { - Should be/have } \\
\text { - Non-toxic and non-irritant. } \\
\text { - Non-carcinogenic. } \\
\text { - Should not cause any systemic reactions. } \\
\text { - Should be cariostatic thus preventing secondary caries formation. }\end{array}$ \\
\hline Chemical & $\begin{array}{l}\text { - Should be chemically inert. } \\
\text { - Solubility of the cement in oral fluids or any other fluids being taken by the patient should be negligible } \\
\text { (maximum allowable solubility of cements in oral conditions is } 0.2 \% \text { ). } \\
\text { - Should bond chemically to the enamel and dentin. } \\
\text { - PH should be neutral. }\end{array}$ \\
\hline Rheological & $\begin{array}{l}\text { Should be/have } \\
\text { - Low film thickness to enable the easy flow of luting cement. } \\
\text { - Longer mixing and working time. } \\
\text { - Shorter setting time. }\end{array}$ \\
\hline Mechanical & $\begin{array}{l}\text { Should be/have } \\
\text { - High compressive strength to withstand the masticatory forces. } \\
\text { - High tensile strength to reduce the brittleness. } \\
\text { - High modulus of elasticity. } \\
\text { - Exhibit minimum dimensional changes on setting. } \\
\text { - Restoration should take and retain a smooth surface finish. } \\
\text { - Should bond chemically to the enamel and dentin. }\end{array}$ \\
\hline Thermal & $\begin{array}{l}\text { Should be/have } \\
\text { - Good thermal insulator. } \\
\text { - Coefficient of thermal expansion (COTE) should be similar to the tooth and artificial prosthesis. }\end{array}$ \\
\hline Optical/aesthetic & $\begin{array}{l}\text { - Should not alter the color of the tooth and artificial restorations/prosthesis. } \\
\text { - Should have adequate radiopacity to enable detection of secondary caries and detection of incompletely filled } \\
\text { cavities due to trapped air. }\end{array}$ \\
\hline Miscellaneous & $\begin{array}{l}\text { Should be /have } \\
\text { - Easy to manipulate. } \\
\text { - Inexpensive. } \\
\text { - Longer shelf life. }\end{array}$ \\
\hline
\end{tabular}

\subsection{Ideal Requirements of Luting Cements $[1,2,3,16,17,18,19,20]$}

Having completed a thorough analysis of the situation it is possible to develop a list of requirements for a luting material to meet the need of clinical durability. The requirements of a luting material can be categorized into biological, chemical, rheological, physical and mechanical, thermal, and esthetic requirements, which help as guidelines in the selection of a suitable luting agent in clinical practice. Various ideal requirements of luting agents are discussed in Table 1.

\subsection{Zinc Phosphate Cements}

Zinc phosphate cement is the oldest of the luting cements; it has been used in dentistry to secure cast restoration for about 130 years and it serves as standard cement with which newer cements can be compared as it has the longest track record. Zinc phosphate cement is also called as "crown and bridge cement" or "zinc 
oxyphosphate cement" [2,3,21]. According to American Dental Association (ADA) specification number 8; type I form is used for luting applications. Type I form has fine grained particles with the film thickness of 25 microns $(\mu \mathrm{m})$ or less, which enables the luting agent to flow or spread easily between the tooth and the artificial restoration $[1,2,3]$.

\subsubsection{Composition}

Zinc phosphate cement is dispensed in the form of powder and liquid system and/or preproportioned capsules. Powder is available in variety of shades such as yellow, gray, golden brown, pink and white $[1,2]$.

Powder mainly contains zinc oxide (ZnO) (90.2\%), magnesium oxide (MgO) (8.2\%), silicon dioxide (1.4\%) which acts as an inactive filler, and other oxides (0.2\%) like bismuth trioxide, calcium oxide and barium oxide, which are added to modify the working characteristics and final properties of the set cement [1,2,3,4,21]. The magnesium oxide is added to reduce the sintering temperature of $\mathrm{ZnO}$ during calcination process, and imparts white colour to the cement [2,21].

The powder is manufactured by a process called sintering. The ingredients of the powder are mixed and heated at temperatures between $1000^{\circ} \mathrm{C}$ and $1400^{\circ} \mathrm{C}$ for 4 to 8 hours. The cake formed is then ground into a fine powder [2].

Zinc phosphate liquid mainly contains aqueous solution of phosphoric acid (38.2\%), water (36\%), which controls the rate of setting reaction, and also containing a buffering agent such as aluminium phosphate or zinc phosphate (16.2\%). In addition, zinc (Zn) and aluminium (Al) also can be added in less quantities they supply additional $\mathrm{Zn}$ and $\mathrm{Al}$ ions $[2,3,4,21]$. The water content of the liquid is established by manufacturer and it should be maintained, otherwise the chemical equilibrium may be disturbed. Either loss or gain of water from the liquid impairs the physical and mechanical properties of the resultant cement. With repeated opening of the bottle over a period of time the water-acid ratio of the remaining liquid may be altered [21]. If the water content is insufficient in the liquid, it results in the formation of crystals on the wall of the bottle, or general cloudiness, however, if the water is absorbed by the liquid no change in the appearance can be observed $[3,21]$. The liquid is produced by adding aluminum and sometimes zinc or their compounds into orthophosphoric acid solution [2].

\subsubsection{Chemistry of Setting}

When the powder is mixed with the liquid, the phosphoric acid attacks the surfaces of the powder particles, dissolves the $\mathrm{ZnO}$ and other oxides and forms acid zinc phosphate with simultaneous release of heat. The $\mathrm{Al}$ of the liquid is essential for cement formation that complexes with the phosphoric acid to form zinc aluminophosphate gel. A noncohesive, crystalline matrix of hopeite that is $\mathrm{Zn}_{3}\left(\mathrm{PO}_{4}\right)_{2}$. $4 \mathrm{H}_{2} \mathrm{O}$ would be formed if powder did not contain $\mathrm{Al}[2,21]$. The set zinc phosphate cement is essentially a hydrated amorphous network of zinc phosphate that surrounds unreacted particles of zinc oxide [2,19].

These cements do not exhibit bactericidal properties. In order to provide bactericidal properties these cements were modified with copper, silver and fluorides [2].
However, these cements were not much used due to their high acidity, solubility and lack of adequate strength $[4,18,22,23]$.

\subsection{Zinc Polycarboxylate Cement}

Polycarboxylate cement is also called as polyacrylate cement. Smith discovered zinc polycarboxylate cements. It was the first cement system developed with a potential for adhesion to tooth structure [2,21]. It is primarily used for cementation of restorations and thermal insulating base. It is also used as an intermediate restoration and luting agent for orthodontic purposes [2].

\subsubsection{Composition}

Polycarboxylate cements are powder and liquid system or single system cements. The liquid is an aqueous solution of polyacrylic acid and copolymer, the powder is similar in composition to that used with zinc phosphate cement, principally zinc oxide with some magnesium oxide. Stannic oxide may be substituted for magnesium oxide and it also contains small quantities of stannous fluoride, and other salts that modify the setting time and enhance the manipulation characteristics. The most important additive is stannous fluoride, which increase the strength of the cement and also acts as a source of fluoride which may impart anticariogenic properties of the cement $[2,3,20,21]$.

The powder of the zinc Polycarboxylate cement is manufactured by sintering process. All the ingredients of the powder are sintered at temperature between $1000^{\circ} \mathrm{C}$ and $1400^{\circ} \mathrm{C}$ into a cake. The ingredients melt in the presence of fluoride, which acts as a fusing agent to form an ion leachable glass mass. The fused mass is then pulverized to form a powder and sieved to obtain the desired particle size [2].

\subsubsection{Chemistry of Setting}

When the powder and liquid are combined the cement forming mechanism is thought to be a reaction of zinc ions with polyacrylic acid via the carboxyl group. The zinc can also react with the carboxyl group of adjacent polyacrylic acid chain so that an ionically cross-linked structure is formed. Thus the set cement consists of zinc oxide particles dispersed in a structure less matrix of zinc polycarboxylate. In the single system polycarboxylate cement, the polycacrylic acid is dried and the powdered acid is mixed with water, the polyacrylic acid goes into solution and the setting proceeds as described for conventional powder and liquid system [2,21].

\subsection{Glass Ionomer Cements (GIC)}

Wilson and Kent developed Glass Ionomer Cements in 1969. Glass ionomer cements were developed in an attempt to capitalize on the favorable properties of both silicate and polycarboxylate cements. Glass ionomer is the generic name of a group of materials that use silicate glass powder and an aqueous solution of polyacrylic acid. This material acquires its name from its formulation of glass powder and an ionomeric acid that contains $\mathrm{COOH}$ groups. Glass ionomer cements are also referred to as polyalkanoate cements or ASPA (Aluminosilicate polyacrylic acid) cements. These cements contain an ion 
leachable glass, which is mainly composed of fluoroaluminosilicate glass and a polyelectrolyte (polyacrylic acid) as liquid. The ion leachable glass can react with water-soluble polymer acid to yield cement. However, the early version of glass ionomer cement had several undesirable characteristics that made this cement not a very popular one in its early years. Then considerable researches have been carried out over the last 20 years. Dental profession has been benefited with an improved physical properties and better handling characteristics of the material. These cements can chemically bond to enamel and dentin and have the ability to release fluoride with superior physical and mechanical properties [2,21,24,25,26].

\subsubsection{Composition}

These cements are available in powder and liquid system, and are also available in preproportioned capsules. Powder contains silica, alumina, fluorides like calcium fluoride, aluminium fluoride, and sodium aluminium fluoride. Fluorides act as fluxes and also as anticariogenic agents. The powder is manufactured by sintering process. The liquid mainly contains poly acrylic acid with copolymers, and also contains tartaric acid and water. Water serves as a reaction medium initially and slowly hydrates the cross-linked matrix [2].

\subsubsection{Chemistry of Setting}

The setting reaction is an acid-base reaction between the acidic polyelectrolyte and the aluminosilicate glass. When the powder and liquid are mixed together, the acid of the liquid attacks the surface of the glass particles and releases calcium, aluminum, sodium and fluoride ions into the aqueous medium, probably in the form of complexes. The salts hydrate to form a gel matrix and the unreacted glass particles are sheathed by silica gel, which arises from removal of cations from the surface of the particles $[1,2,3,4,19,21]$.

The presence of tartaric acid plays a significant part in controlling the setting characteristics of the material. It helps in breakdown of the surface layers of the glass particles and rapidly liberates aluminium ions. Tartaric acid forms complex with these ions. This results in delay in the working time since free aluminum ions are not immediately available for reaction with the polyacid. The initial onset of setting is further inhibited by the tartaric acid preventing unwinding and ionization of the poly acid chains $[1,2,3]$.

\subsection{Resin Based Cements}

Resin cements were introduced in the mid-1980s, these materials have a setting reaction based on polymerization. One of the first resin cements was marketed by Dentsply/Caulk under the name Biomer, around 1987. Resin cements essentially contain polymers to which fillers have been added to reduce the coefficient of thermal expansion (CoTE) and water sorption thereby increasing the strength of polymers. [27,28] Fluoride agents were also added [29]. These are widely used cements for nonmetallic restorations, resin-bonded fixed partial dentures, ceramic crowns, and porcelain veneers, as well as ceramic and resin composite inlays and onlays [2]. The important hitches of these cements include lack of bonding to enamel and dentin leading to microleakage; higher film thickness, and pulpal irritation caused by leaching out of unreacted monomer [30], and also tend to discolour due to high residual amine levels after polymerization [1,2,31]. Resin cements with a dentin bonding agent have provided a superior retention of crown on teeth compared to using zinc phosphate cement [2].

Aromatic Dimethacrylate-Based Resin Cements were also discussed in the literature [5]. Dr. Bowen developed the first multifunctional methacrylate used in dentistry, called bis-GMA or Bowen's resin. The bis-GMA (2,2bis[4-(2 hydroxy-methacryloxypropoxy) phenyl] propane) resin can be described as an aromatic ester of dimethacrylate, synthesized from an epoxy resin and methyl methacrylate [2,32,33]. Bis-GMA is extremely viscous and a low viscosity dimethacrylate, such as triethylene glycol dimethacrylate (TEGDMA) is blended with it to reduce the viscosity. Resin cements are available as powder/liquid, encapsulated, or paste/paste systems and are classified into three types based on the method of polymerization as chemical-cured, lightcured and dualcured $[2,33]$.

\subsubsection{Resin Modified Glass Ionomer Cement (RMGIC)}

This cement is obtained by addition of water soluble resin monomer into the liquid of traditional glass ionomer cement. Thus, the goal of this process is to decrease the sensitivity against water and increase the resistance of glass ionomer cement [2,3,31]. These cements are essentially hybrid formulations of resin and glass ionomer components [29]. These are available as dual- or tri-cured materials. RMGICs provide better bond strengths and release greater amounts of fluoride compared to conventional glass ionomer cements. The mechanical properties of all glass ionomer cements increase with time, which perhaps contributes to their clinical success $[34,35,36]$. These cements bond to tooth structure $[1,2]$, have low microleakage when mixed properly and when applied to moist dentin produce little post-cementation thermal sensitivity [37]. The RMGICs are relatively easy to handle and are suitable for routine application with metal-based crown and bridgework $[2,29]$. It is not recommended to cement certain all-ceramic restorations, like veneers and pressed ceramics, with hybrid cements because of the potential for post-cementation fractures. It is believed that these cements undergo hydrolytic expansion after water sorption, which leads to crack propagation in the overlying restoration.

\subsubsection{Self-adhesive Cements}

Self-adhesive cements are the newest category of resin cements and these are aesthetically appropriate for cementing all-ceramic crowns and porcelain inlays and onlays. Self-adhesive cements contain acrylic or diacrylate monomers and specific adhesive monomers that are sufficiently acidic to produce their self-adhesive properties. They are dual-cured and can be used most effectively when bonding to dentin. They have got simplified cementation procedure as they do not require a separate adhesive bonding agent like in conventional resin cements $[2,35,38]$. Indications and contra-indications of various luting agents are listed in Table 2. 
Table 2. Indications and contraindications for luting agent

\begin{tabular}{|l|c|c|c|c|c|}
\hline \multirow{2}{*}{ Type of prosthesis } & \multicolumn{5}{|c|}{ Type of Luting Agent } \\
\cline { 2 - 6 } & Zinc Phosphate & Zinc Polycarboxylate & Glass Ionomer & RMGIC & Resin Cement \\
\hline Cast crown, PFM crown. & Indicated & Indicated & Indicated & Indicated & Indicated \\
\hline $\begin{array}{l}\text { Pressed ceramic crown, ceramic } \\
\text { inlay, ceramic veneer, resin bonded } \\
\text { FPD }\end{array}$ & Contra-indicated & Contra-indicated & Contra-indicated & Contra-indicated & Indicated \\
\hline $\begin{array}{l}\text { Patient with history of post-treatment } \\
\text { sensitivity }\end{array}$ & - & Indicated & - & - & Contra-indicated \\
\hline Crown or FPD with poor retention & Contra-indicated & Contra-indicated & Contra-indicated & Contra-indicated & Indicated \\
\hline Cast post and core & Indicated & Contra-indicated & Indicated & Indicated & Indicated \\
\hline
\end{tabular}

\section{Properties of Luting Agents}

The selection of a luting agent for luting of various prostheses is mainly based on their properties. Most important properties of luting agents include biological, rheological, physical, and mechanical properties. Luting agent has different physical, mechanical and biological characteristics resulting from its chemical structure $[1,2,3,4,39]$. Various properties of luting agents are listed in Table 3.

Table3. Properties of Luting cements [2-4,32-76]

\begin{tabular}{|c|c|c|c|c|c|c|c|c|c|c|}
\hline \multirow{3}{*}{ Luting agent } & \multirow{3}{*}{$\begin{array}{c}\text { Biological } \\
\text { (Effect on Pulp) }\end{array}$} & \multicolumn{3}{|c|}{ Chemical } & \multicolumn{3}{|c|}{ Rheological } & \multirow{2}{*}{\multicolumn{3}{|c|}{ Physical \& Mechanical }} \\
\hline & & \multicolumn{2}{|c|}{$\mathrm{pH}$} & \multirow{2}{*}{$\begin{array}{l}\text { Solubility in } \mathrm{H}_{2} \mathrm{O} \text { at } \\
24 \text { hrs. }\end{array}$} & \multirow{2}{*}{$\begin{array}{l}\text { WT } \\
(\mathrm{min})\end{array}$} & \multirow[b]{2}{*}{ ST (min) } & \multirow{2}{*}{$\begin{array}{c}\mathrm{FT} \\
(\mu \mathrm{m})\end{array}$} & & & \\
\hline & & $2 \mathrm{~min}$. & 24 hrs. & & & & & $\begin{array}{c}\mathrm{CS} \\
(\mathrm{MPa})\end{array}$ & $\begin{array}{c}\text { TS } \\
(\mathrm{MPa})\end{array}$ & $\begin{array}{l}\mathrm{MOE} \\
(\mathrm{GPa})\end{array}$ \\
\hline Zinc Phopsphate & Severe Irritant & 2.14 & 6 & $0.2 \%$ & $3-6$ & $5-14$ & 25 & 103.4 & $5-7$ & 13 \\
\hline Zinc Polycarboxylate & Mild effect & 3.42 & 7 & $0.06 \%$ & $2.5-3.5$ & $6-9$ & $25-30$ & $55-90$ & 8-12 & $4-5$ \\
\hline Glass Ionomer & Mild effect & 2.33 & 5.68 & $0.4-1.5 \%$ & $2-4$ & $6-9$ & 25 & $90-220$ & $6-7$ & 8-11 \\
\hline RMGIC & Mild effect & $3-5$ & & $0.07-0.4 \%$ & $2-4$ & $5-6$ & 25 & $85-126$ & $13-24$ & $2.5-7.8$ \\
\hline Methacrylte resin cements & Moderate effect & & & $0.0-0.01 \%$ & & $2-4$ & $<25$ & $70-172$ & & 2.1-3.1 \\
\hline
\end{tabular}

WT $=$ Working Time

ST $=$ Setting Time

$\mathrm{CS}=$ Compressive Strength

TS $=$ Tensile Strength

MOE $=$ Modulus of Elasticity.

\subsection{Biological Properties}

Biological considerations are the foremost properties to be discussed for any biomaterial. Ideally, a dental biomaterial should be harmonious to the oral soft and hard tissues. However, many luting agents are acidic in nature with varying $\mathrm{pH}$ and cause mild to severe pulpal irritation. Among all luting agents zinc phosphate cements are highly acidic and cause severe pulpal irritation. Zinc Polycarboxylate cement is most biocompatible to the pulp as its liquid contains polyacrylic acid with high molecular weight and also the $\mathrm{pH}$ of the liquid is rapidly neutralized by the addition of the powder $[2,40]$. GICs have mild effect on the pulp. A resin-based desensitizer can be placed on the prepared tooth prior to the cementation to decrease the potential for post cementation sensitivity when using zinc phosphate or glass ionomer cements. These desensitizers should not adversely affect crown retention [41]. GICs cause potential post-cementation sensitivity $[42,43]$ because of low initial setting $\mathrm{pH}$ and the setting reaction sensitivity to moisture contamination/dessication. These cements are excellent for general prosthodontic use. Fluoride release may be beneficial for some patients as it provides cariostatic effect [44-59]. One should avoid using glass ionomer with hypersensitive teeth. Resin cements have moderate effect on pulp. Release of unreacted monomer into oral cavity has been reported to cause abnormalities or lesions in several organs. Experimental and clinical studies have documented that monomers may cause a wide range of adverse health effects such as irritation to skin, eyes, and mucous membranes, allergic dermatitis, stomatitis, asthma, neuropathy, disturbances of the central nervous system, liver toxicity, and fertility disturbances [30,60].

\subsection{Chemical and Rheological Properties}

The $\mathrm{pH}$ of the freshly mixed zinc phosphate is less than 2.0 but rises to 5.9 within 24 hours and is neutral ( $\mathrm{pH} 7.0$ ) by 48 hours. As the rate of reaction is so rapid the operator may not be having adequate working time. The working time can be prolonged by mixing the material on chilled glass slab [27]. Since the setting reaction of zinc phosphate cement is an exothermic reaction, mixing a small amount of the powder to the liquid and adding the remaining powder in small increments also prolongs working time. A frozen mixing slab allows increased powder to be added to the mixture, which compensates for incorporating water collecting on the slab and increases working time without reducing the strength of the cement [28]. Zinc Polycarboxylate cements also have shorter working time and their solubility is greater than other cements. Zinc poly carboxylate cements exhibit a unique quality such as pseudoplasticity [61,62]. Initial solubility of GICs is high as they release fluoride ions, which are useful for anticariogenic property [2,63]. Glass ionomers may undergo erosion as the $\mathrm{pH}$ changes in the oral cavity $[2,64]$ and also by the formation of soluble complexes of cement cations with certain anions, particularly citrates [2]. GICs have low film thickness and maintains constant viscosity for a short time after mixing $[65,66]$. RMGICs are less sensitive to early moisture contamination and desiccation during setting and less soluble than the glass- 
ionomer cement [38,67]. RMGICs have adequate film thickness $[68,69]$.

\subsection{Physical Properties}

All luting agents are good thermal insulators so pulp can be protected from the thermal shocks. They are also good electrical insulators in dry conditions; however, galvanism may results in wet conditions in conjunction with metallic prostheses. COTE of glass ionomer cement is closer to the natural tooth so it will not undergo much dimensional changes as the temperature changes in the oral cavity. All luting agents are opaque except glass ionomer and resin cements. Resin cements and glass ionomer cements are most commonly used for luting of all-ceramic restorations since they are translucent $[2,3,4,5]$.

\subsection{Mechanical Properties}

Zinc phosphate and resin modified glass ionomer cements have comparable compressive strength. Modulus of elasticity of zinc phosphate cement is higher than other luting agents. Glass ionomer and zinc poly carboxylate cements bond chemically to the tooth structure $[70,71,72]$ and other luting agents bond via mechanical and/or micro mechanical bonding mechanism [2]. The adhesive bond of Polycarboxylate cement is primarily to enamel although a weaker bond to dentin also forms as a result of chelation reaction between the carboxyl groups of the cement and calcium in the tooth structure; hence, the more mineralised the tooth structure, the stronger the bond. This cement is hydrophilic, therefore it is capable of wetting dentinal surfaces [10,22,73,74]. Resin cements require some adhesive agents to provide strong bonding to the tooth structure [73,74]. RMGICs and resin cements exhibit polymerization shrinkage [48,49,75,76]. Advantages and disadvantages of various luting agents are lited in Table 4 and Table 5 respectively.

Table 4. Advantages of Luting agents [1-5, 32-61]

\begin{tabular}{|c|c|c|c|c|}
\hline Zinc Phosphate & Zinc Polycarboxy-late & Glass Ionomer & RMGIC & Resin Cement \\
\hline $\begin{array}{l}\text { 1. Good compress- ive } \\
\text { strength. } \\
\text { 2. Adequate film thickness } \\
(25 \mu \mathrm{m}) \text {. } \\
\text { 3. Reasonable working time. } \\
\text { 4. Can be used in regions of } \\
\text { high mastic-atory stress or } \\
\text { long span prosthesis. }\end{array}$ & $\begin{array}{l}\text { 1. Biocompatib-ility } \\
\text { with the dental pulp. } \\
\text { 2. Adequate resistance } \\
\text { to water dissolution. } \\
\text { 3. Pseudoplastic. } \\
\text { 4. Favourable tensile } \\
\text { strength. } \\
\text { 5. Chemical bonding }\end{array}$ & $\begin{array}{l}\text { 1. Anticariogenic. } \\
\text { 2. Ability to absorb fluoride } \\
\text { recharge from the oral } \\
\text { environment makes it the } \\
\text { cement of choice in patients } \\
\text { with high caries rate. } \\
\text { 3. Coefficient of thermal } \\
\text { expansion similar to tooth } \\
\text { 4. Translucent. } \\
\text { 5. Adequate resistance to acid } \\
\text { dissolution } \\
\text { 6. Low film thickness and } \\
\text { maintains constant viscosity } \\
\text { for a short time after } \\
\text { mixing. } \\
\text { 7. Chemical bonding. }\end{array}$ & $\begin{array}{l}\text { 1. Improved compressive } \\
\text { strength, diametral tensile } \\
\text { strength, and flexural strength. } \\
\text { 2. Less sensitive to early } \\
\text { moisture contamination and } \\
\text { desiccation during setting. } \\
\text { 3. Less soluble than the glass- } \\
\text { ionomer cement. } \\
\text { 4. Easy to manipulate } \\
\text { 5. Adequately low film } \\
\text { thickness. } \\
\text { 6. Fluoride release similar to } \\
\text { conventional GIC. } \\
\text { 7. Minimal post-operative } \\
\text { sensitivity } \\
\text { 8. High bond strength to moist } \\
\text { dentin. }\end{array}$ & $\begin{array}{l}\text { 1. Superior compressive } \\
\text { and tensile strengths. } \\
\text { 2. Low solubility } \\
\text { 3. Available in wide } \\
\text { range of shades and } \\
\text { translucencies. }\end{array}$ \\
\hline
\end{tabular}

Table 5. Disadvantages of Luting agents [1-5, 32-61]

\begin{tabular}{|c|c|c|c|c|}
\hline Zinc Phosphate & Zinc Polycarboxylate & Glass Ionomer & RMGIC & Resin Cement \\
\hline $\begin{array}{l}\text { 1. Highly acidic. } \\
\text { 2. Low tensile strength. } \\
\text { 3. No chemical bonding. } \\
\text { 4. Solubility in oral fluids. } \\
\text { 5. Lack of antibacterial } \\
\text { properties. }\end{array}$ & $\begin{array}{l}\text { 1. No resistance to acid } \\
\text { dissolution. } \\
\text { 2. Manipulation critical. } \\
\text { 3. Early rapid rise in } \\
\text { film thickness that } \\
\text { may interfere with } \\
\text { proper seating of a } \\
\text { casting }\end{array}$ & $\begin{array}{l}\text { 1. Initial slow setting. } \\
\text { 2. Sensitivity to early moisture } \\
\text { contamination and desiccation } \\
\text { 3. MOE is lower than zinc } \\
\text { phosphate. } \\
\text { 4. Post ceme-ntation sensitivity. } \\
\text { 5. Insufficient wear-resistance }\end{array}$ & $\begin{array}{l}\text { 1. Polymeriz-ation shrink- } \\
\text { age. } \\
\text { 2. More water sorption due } \\
\text { to the presence of } \\
\text { HEMA. } \\
\text { 3. Although rare, may elicit } \\
\text { an allergic response due } \\
\text { to free monomer. } \\
\text { 4. Cement bulk is very hard } \\
\text { and difficult to remove. }\end{array}$ & $\begin{array}{l}\text { 1. Severe pulpal reactions } \\
\text { when applied to cut vital } \\
\text { dentin. } \\
\text { 2. High film thickness } \\
\text { 3. Marginal leakage due to } \\
\text { polymerization shrinkage } \\
\text { 4. Lack of acnticariogenic } \\
\text { properties. } \\
\text { 5. Low MOE. } \\
\text { 6. No Chemical bonding. } \\
\text { 7. Meticulous and critical } \\
\text { manipulate-on technique }\end{array}$ \\
\hline
\end{tabular}

\section{Conclusion}

Restorative dentistry has been going through numerous changes as an outcome of clinical applications and development of new materials. Several new materials are available differing each other in content and physical attributions. Therefore it may be difficult to the dentist to make a choice amongst so many alternative products. Each luting agent has different physical, mechanical and biological characteristics resulting from its chemical structure. So, to achieve a clinical success, the clinician should be aware of the qualities, advantages and disadvantages of each type of cement.

\section{References}

[1] Anusavice KJ, Phillip's Science of Dental Materials, WB Saunders Co., Philadelphia, 2003, $11^{\text {th }}$ Edition, 443-493.

[2] Rama Krishna Alla, Dental Materials Science, Jaypee Brothers Medical Publishers Pvt Limited, New Delhi, India, 2013, $1^{\text {st }}$ Edition, 91-125.

[3] Sakaguchi RL, Powers JM, Craig's Restorative Dental Materials, Elsevier, Mosby, Philadelphia, 2011, $12^{\text {th }}$ Edition, 327-348.

[4] J'Obrien W, Dental Materials and their selection, $3^{\text {rd }}$ edition, quintessence Publishing Co. Inc, 2002, 132-155.

[5] Ladha K, Verma M, Conventional and Contemporary Luting Cements: An Overview, J Indian Prosthodont Soc, 10(2), 79-88, June 2010. 
[6] Pameijer CH, A Review of luting agents, Oral Health Group, 1-11, Nov 2013 (http://www.oralhealthgroup.com/news/a-review-ofluting-agents-cornelis-h-pameijer-dmd-dscphd/1002702355/?\&er $=$ NA).

[7] de la Macorra JC, Pradíes G, Conventional and adhesive luting cements, Clin Oral Invest,6:198-204, Nov 2002.

[8] Jivraj SA, Kim TH, Donovan TE. Selection of luting agents, part 1. J Calif Dent Assoc, 34(2):149-160, Feb 2006.

[9] Kim TH, Jivraj SA, Donovan TE. Selection of luting Agents, part 2. J Calif Dent Assoc,34(2):161-166, Feb 2006.

[10] Smith DC, A new dental cement. Br. Dent. J, 124(9), 381-4, Nov 1968.

[11] Wilson AD, Kent RE.: A new translucent cement for dentistry. The glass ionomer cement, Br. Dent. J, 132(4), 133-135, Feb 1972.

[12] Mesu FP, Degradation of luting cements measured in vitro, $J$. Dent. Res, 61(5), 665-72, May 1982.

[13] Zhen Chun Li, White SN, Mechanical properties of dental luting cements, J Prosthet Dent, 81(5), 579-609, May 1999.

[14] Mitchell CA, Douglas WH, Comparison of the porosity of hand mixed and capsulated glass-ionomer luting cements, Biomater, 18, 1127-1131, Aug 1997.

[15] Oilo G, Luting cements: A review and comparison. Int. Dent. J, 41, 81-8, Apr 1991.

[16] Gattani-Lorente MA, Dupuis V, Payan J, Moya F, Meyer JM, Effect of water on the physical properties of resin-modified glass Ionomer cements, Dent Mater, 159(1), 71-78, Jan 1999.

[17] Gattani-Lorente MA, Godin C, Meyer JM, Mechanical behavior of glass ionomer cements affected by long-term storage in water, Dent. Mater, 10, 37-44, 1994.

[18] McCabe JF, Angus W.G. Walls, Applied Dental Materials, Blackwell publishing company, UK, $19988^{\text {th }}$ Edition, 245 -264.

[19] Combe EC. Notes on dental materials, Longman Group Limited, $19865^{\text {th }}$ edition.

[20] Ebru SÜMER, Yalçın DEĞER, Contemporary Permanent Luting Agents used in Dentistry: A Literature Review, Int Dent Res, 1(1), 26-31, 2011.

[21] Ferrance JF, Materials in Dentistry: Principles and Applications. Lippincott Williams and Wilkins, Philadelphia, $2^{\text {nd }}$ edition, 2001, 59-116.

[22] Russell D, ZNP red copper cement. Materia Medica, 1-3, 2001.

[23] Overman PR, Biofilm: A new view of plaque. J Contemp Dent Pract, 1(3), 18-29, Aug 2000.

[24] Upadhya NP, Kishore G, Glass Ionomer Cement - The Different Generations, Trends Biomater. Artif. Organs, 18 (2), 158-165, Jan 2005.

[25] Croll TP, Berg JH, Glass Ionomer cement systems, Inside Dent, 6(8), 82-84, 2010.

[26] Mohammadi Z, Shalavi S, Clinical applications of glass ionomers in endodontics: a review, Int Dent J, 62: 244-250, Oct 2012.

[27] Kendzoir GM, Leinfelder KF, Characteristics of zinc phosphate cements mixed at sub-zero temperatures [Abstract no.134], J Dent Res, 55(Special Issue B), B95, 1976.

[28] Myers CL, et al., A comparison of properties for zinc phosphate cements mixed on room temperature and frozen slabs, $J$ Prosthet Dent, 40(4), 409-12, 1978.

[29] Pameijer, A Review of luting agents, Int J Dent, 2012: 1-7. Article ID 752861.

[30] Gosavi SS, Gosavi SY, Alla RK, Local and Systemic Effects of Unpolymerised Monomers, Dent Res J, 7(2), 82-87, SummerAutumn 2010

[31] Rosensteil SF, et al., Dental luting agents: a review of the current literature, J Prosthet Dent, 80, 280, Sep 1998.

[32] Bowen RL, Properties of a silica-reinforced polymer for dental restorations, J Am Dent Assoc, 66, 57-64, Jan 1963.

[33] Ravi RK, Alla RK, Shammas M, Devarhubli A, Dental Composties - A Versatile Restorative material: An Overview, Ind J Dent Sci, 5(5), 111-115, Dec 2013.

[34] Xu X, Burgess JO, Compressive strength, fluoride release and recharge of fluoride-releasing materials, Biomater, 24(14), 245161, June 2003.

[35] Mc Comb D, Adhesive luting cements - classes, criteria, and usage, Compend Contin Educ Dent, 17(8), 759-62, Aug 1996.

[36] Robertello FJ, Coffey JP, Lynde TA, King P, Fluoride release of glass ionomer-based luting cements in vitro, J Prosthet Dent,82(2), 172-6, Aug1999.
[37] Rosensteil SF, Rashid RG, Post cementation hypersensitivity: scientific data versus dentists' perceptions, J Prosthodont, 12(2), 73-81, Jun 2003.

[38] Tjan AHL, Tao L, Seating and retention of complete crowns with a new adhesive resin cement, $J$ Prosthet Dent, 67(4), 478-483, Apr 1992.

[39] Griffith JR, Cannon RWS, Cementation-materials and techniques, Aust Dent J, 19(2), 93-99, Apr 1974.

[40] Charlton DG, Moore BK, Swartz ML, Direct surface $\mathrm{pH}$ determination of setting cements, Oper Dent, 16(6), 231-238, Nov-Dec 1991.

[41] Swift EJ, Lloyd AH, Felton DA, The effect of resin desensitizing agents on crown retention, J Am Dent Assoc,128(2), 195-200, Feb 1997.

[42] Smith DC, Ruse ND, Acidity of glass ionomer cements during setting and its relation to pulp sensitivity, J Am Dent Assoc, 112(5), 654-657, May 1986.

[43] Johnson GH, Powell LV, Derouen TA, Evaluation and control of postcementation pulpal sensitivity of Zinc phosphate and glassionomer cements, J Am Dent Assoc, 124(11), 39-46, Nov 1993.

[44] Attar N, Onen A, Fluoride release and uptake characteristics of esthetic restorative materials, J Oral Rehabil, 29(8), 791-8, Aug 2002.

[45] Bell A, Creanor SL, Foye RH, Saunders WP, The effect of saliva on fluoride release by a glass-ionomer filling material, $J$ Oral Rehabil, 26(5), 407-12, May 1999.

[46] De Moor RJ, VerBeeck RM, DE Maeyer EA, Fluoride release profiles of restorative glass-ionomer formulations, Dent Mater, 12(2), 88-95, Mar 1996.

[47] Dhull KS, Nandlal B, Comparative evaluation of fluoride release from PRG-composites and compomer on application of topical fluoride: An in-vitro study, J Indian Soc Pedo Prev Dent, 27(1), 27-32, Jan-Mar 2009.

[48] Setty JV, Singh S, Subba Reddy VV, Comparision of the effect of topical fluorides on the commercially available conventional Glass Ionomers and Polyacid modified Composite resins- An in-vitro study, J Indian Soc Pedo Prev Dent, 21(2), 55-69, Jun 2003.

[49] Preston AJ, Mair LH, Agalamanyi EA, Highham SM, Fluoride release from aesthetic dental materials, J Oral Rehabil, 26(2), 123129, Feb 1999.

[50] Lee SY, Dong DR, Huang HM, Shih YH, Fluoride ion diffusion from glass ionomer cement, J Oral Rehabil, 27(7), 576-586, Jul 2000.

[51] Kiran A, Hegde V, A short term comparative analysis of Fluoride release from a newly introduced Glass Ionomer Cement in deionised water and lactic acid, J Int Oral Health, 2(2), 71-77, Aug 2010.

[52] Moreau JL, Xu HK, Fluoride releasing restorative materials: Effects of $\mathrm{pH}$ on mechanical properties and ion release, Dent Mater, 26(11), e227-e235, Nov 2010.

[53] Pithon MM, Dos Santos RL, Oliveira MV, Ruellas AC, Romano FL, Metallic brackets bonded with resin-reinforced glass ionomer cements under different enamel conditions, Angle Orthodont, 76(4), 700-4, Jul 2006.

[54] Pereira TB, Jansen WC, Pithon MM, Souki BQ, Tanaka OM, Oliveira DD, Effects of enamel deproteinization on bracket bonding with conventional and resin-modified glass ionomer cements, Eur J Orthod,35(4), 442-6, Aug 2013.

[55] Vermeersch G, Leloup G, Vreven J, Fluoride release from glass ionomer cements, compomers, and resin composites, J Oral Rehabil, 28, 26-32, Jan 2001.

[56] Weigand A, Buchalla W, Attin T, Review of fluoride-relaesing restorative materials-fluoride release and uptake characteristics, antibacterial activity, and influence on caries formation, Dent Mater, 23(3), 343-362, Mar 2007.

[57] Mousavinasab SM, Meyers I, Fluoride release by glass ionomer cements, compomer, and giomer, Dent Res J, 6(2), 75-81, Autumn 2009.

[58] Qvist V, Poulsen A, Teglers PT, Mjor IA, Fluorides leaching from restorative materials and the effect on adjacent teeh, Int Dent $J$, 60(3), 156-160, Jun 2010.

[59] Patil S, Goud M, Sajjan, Effect of short-term Fluoride release from various restorative cements on enamel demineralization: A in vitro study, Int J Prostho Rest Dent, 1(1), 29-33, April-June 2011.

[60] Nicholson JW, Czarnecka B, The biocompatibility of resinmodied glass-ionomer cements for dentistry, Dent Mater, 24(12), 1702-1708, Dec 2008 
[61] Smith DC, Dental cements. Current status and future prospects. Dent Clin North Am, 6(3), 763-793, 1983.

[62] Rosentiel SF, Land MF, Crispin BJ, Dental luting agents: a review of the current literature, J Prosthet Dent, 80(3), 280-301, Sep 1998.

[63] Wang XY, Yap AU, Ngo HC, Effect of early water exposure on the strength of glass ionomer restoratives, Oper Dent, 31(5), 584589, Sep-Oct2006.

[64] Ravi RK, Alla RK, Shammas M, Ramesh KSV, Non-Carious lesions due to tooth surface loss: A Review, Dental Era - A Journal of Dentistry, 3(3), 35-40, Jul-Sept 2013.

[65] Strutz JM, White SN, Yu Z, Kane CL, Luting cement metal surface physicochemical interactions on film thickness, $J$ Prosthet Dent, 72(2), 128-132, Aug 1994.

[66] Øilo G, Evje DM, Film thickness of dental luting cements, Dent Mater, 2(2), 85-89, Apr 1986.

[67] Cho E, Kopel H, White SN, Moisture susceptibility of resinmodified glass-ionomer materials, Quitessence Int, 269(5), 351358, May 1995.

[68] White SN, Yu Z, Film thickness of new adhesive luting agents, $J$ Prosthet Dent, 67(6), 782-785, Jun 1992.

[69] White SN, Yu Z, Sangsurasak S, In vivo marginal adaptation of cast crowns luted with different cements, J Prosthet Dent, 74(1), 25-32, Jul 1995.
[70] Hosada H, Katsuyama S, Ishikawa T, Fujii B (eds) Glass ionomer dental cement-the materials and their clinical use. Ishiyaku Euroamerica, St Louis, 16-24, 40-46, 1993.

[71] Wilson AD, Prosser HJ, Powis DM, Mechanism of adhesion of polyelectrolyte cements to hydroxyapatite, J Dent Res, 62(5), 590592, May 1983.

[72] Hajizadeh H, Ghavamnasiri M, Namazikhah MS, Majidinia S, Bagheri M, Effect of different conditioning protocols on the adhesion of glass ionomer cement to dentin, J Contemp Dent Pract, 10(4), 9-16, July 2009.

[73] Yamamoto K, Kojima H, Tsutsumi T, Oguchi H, Effects of toothconditioning agents on bond strength of a resin-modified glass ionomer sealant to enamel, J Dent, 31(1), 13-18, Jan 2003.

[74] Diaz-Arnold AM, Vargas MA, Haselton DR, Current status of luting agents for fixed prosthodontics, J Prosthet Dent, 81(2), 135141, Feb 1999.

[75] Sidhu SK, Sheriif M, Watson TF, The effects of maturity and dehydration shrinkage on resin-modified glass-ionomer restorations, J Dent Res, 76(8), 1495-1501, Aug 1997.

[76] Sidhu SK, Watson TF, Resin-modified glass-ionomer cements, Int J Prosthodont, 3(5), 425-429, Sep-Oct 1990 